\title{
PENGARUH PENGGUNAAN BIOSUPLEMEN MENGANDUNG BAKTERI PROBIOTIK SELULOLITIK ASAL RAYAP (Termites sp.) TERHADAP PRODUKTIVITAS ITIK BALI JANTAN
}

\author{
LAKSMI DEWI, M. P1)., N. S. SUTAMA2), G. A. M. KRISTINA DEWI2) \\ 1) Program Studi Magister Ilmu Peternakan, Universitas Udayana Denpasar \\ 2) Fakultas Peternakan,Universitas Udayana Denpasar \\ e-mail: madeputrilaksmidewi@gmail.com
}

\begin{abstract}
ABSTRAK
Penelitian bertujuan mempelajari pengaruh penggunaan biosuplemen mengandung bakteri probiotik selulolitik asal rayap (Termites sp.) terhadap produktivitas itik bali jantan. Isolat bakteri yang digunakan pada penelitian ini adalah isolat bakteri probiotik selulolitik unggul cairan termites 1 dan 2 asal rayap dengan kode BR3.3 dan BR3.5. Rancangan adalah rancangan acak lengkap dengan 5 perlakuan dan 3 ulangan, yaitu $\mathrm{R}_{\mathrm{o}}=$ Ransum basal tanpa menggunakan biosuplemen, $\mathrm{RBCT}_{\mathrm{o}}=$ Ransum basal menggunakan biosuplemen tanpa penambahan inokulan bakteri probiotik selulolitik cairan termites, $\mathrm{RBCT}_{1}=$ Ransum basal menggunakan biosuplemen inokulan bakteri probiotik selulolitik cairan termites unggul $1, \mathrm{RBCT}_{2}=$ Ransum basal menggunakan biosuplemen inokulan bakteri probiotik selulolitik cairan termites unggul 2 dan $\mathrm{RBCT}_{1^{-}{ }_{2}}=$ Ransum basal menggunakan biosuplemen inokulan bakteri probiotik selulolitik cairan termites unggul 1 dan 2 . Hasil penelitian menunjukkan bahwa bobot badan awal, bobot potong, persentase karkas itik yang diberi ransum menggunakan biosuplemen berprobiotik selulolitik asal rayap Termites $s p$ menunjukan hasil yang tidak berbeda nyata $(\mathrm{P}>0,05)$, namun bobot badan akhir, pertambahan bobot badan, konsumsi ransum, konversi pakan dan total kolesterol daging pada penelitian menunjukan hasil yang nyata $(\mathrm{P}<0,05)$. Dapat disimpulkan bahwa penggunaan ransum basal menggunakan biosuplemen inokulan bakteri probiotik selulolitik cairan termites unggul $2\left(\mathrm{RBCT}_{2}\right)$ mampu meningkatkan produktivitas itik bali jantan umur 2-10 minggu.
\end{abstract}

Kata kunci: biosuplemen, itik bali jantan, isolat rayap

\section{THE EFFECT USE OF BIOSUPLEMENT CONTAINING PROBIOTIC BACTERIA OF CELLULOLYTIC TERMITES TO THE PRODUCTIVITY OF BALI DUCKS}

\begin{abstract}
The research aims at analyzing the effect use of probiotic cellulolytic biosuplement termite (Termites sp.) to the productivity of male bali ducks. Bacteria isolates used were first and second preeminent probiotic cellulolytic bacteria isolated derived from termites code BR3.3 and BR3.5. It was designed using a Completely Randomized Design with five treatments and three replicates consists of: basal ration without biosuplement $\left(\mathrm{R}_{\mathrm{o}}\right)$, ration basal with biosupplement but without additional probiotic cellulolytic bacteria inoculant preeminent termites $\left(\mathrm{RBCT}_{0}\right)$, $\mathrm{RBCT}_{1}=$ basal ration with biosuplement probiotic cellulolytic bacteria inoculant preeminent termites $1, \mathrm{RBCT}_{2}=$ basal ration with biosuplement probiotic cellulolytic bacteria inoculant preeminent termites 2 and $\mathrm{RBCT}_{1_{2}}=$ basal ration with biosuplement probiotic cellulolytic bacteria inoculant preeminent termites 1 and 2. The result showed that the initial body weight, slaughter weight and carcass percentage had no significant differences $(\mathrm{P}>0.05)$. In contrast, final body weight, body weight gain, feed consumption, Feed Conversion Ratio and meat total cholesterol were significantly affected $(\mathrm{P}<0,05)$ to the result. It can be concluded that use of basal ration supplemented with biosupplement probiotic cellulolytic bacteria inoculant preeminent termites $2\left(\mathrm{RBCT}_{2}\right)$ can increase productivity of bali duck at the age of 2 up to10 weeks.
\end{abstract}

Keywords: biosupplement, male ducks bali, isolates, Termites sp. 


\section{PENDAHULUAN}

Itik bali merupakan salah satu plasma nutfah asli Indonesia yang memiliki potensi besar sebagai sumber protein hewani (daging), karena itik memiliki kelebihan terutama komposisi gizi, protein yang setara dengan daging dari jenis unggas lainnya, selain harganya yang relatif murah (Dijaya, 2003). Pemanfaatan limbah dan gulma tanaman pangan (enceng gondok dan daun apu) cukup berpotensidijadikan sebagai pakan ternak mengingatproduksitinggi dan berlimpah sehingga tidak bersaing dengan kebutuhan manusia, namun enceng gondok dan daun apu mempunyai keterbatasan yaitu kandungan serat kasar yang tinggi sehingga dapat merugikan peternak. Aplikasi teknologi suplementasidanfermentasi dengan pemanfaatan bakteri unggul yang berasal dari rayap berbasis limbah isi rumen penting dilakukan untuk mengatasi keterbatasan pemanfaatan limbah sebagai pakan ternak (Dewi et al., 2013).

Menurut Partama et al. (2012) isi rumen sapi bali kaya akan nutrient availabel, enzim ( $\alpha$-amilase, galaktosidase, hemiselulase, selulase, dan xilanase) dan mikroba pendegradasi serat sertamikroba probiotik sehingga sangat potensial untuk dimanfaatkan sebagai biosuplemen (suplemen berprobiotik). Hasil penelitian Dewi et al., (2013) mendapatkan penggunaan isi rumen sapi bali sebanyak 20\% mampu menghasilkan biosuplemen dengan kualitas yang baik meliputi kandungan nutrien dan populasi mikroba pendegradasi serat serta probiotik yang tinggisehinggamemberikan hasil yang baik terhadap pertambahan bobot badan itik bali jantan umur 2-10 minggu, namun efisiensi pemanfaatan ransum $(F C R)$ rendah yaitu 5,72 . Lebih lanjut tingginya kandungan serat kasar yang terkandung dalam biosuplemen memiliki kandungan serat kasar yang tinggi (25-35\%), sehingga penggunaannya sebagai biosuplemen perlu diatur dengan baik (Dewi et al., 2013; Mudita et al., 2014).

Upaya penurunan serat kasar yang ada pada biosuplemen yang diproduksi perlu dilakukansehingga menghasilkan biosuplemen yang berkualitas serta mampu menghasilkan produktivitas ternak yang baik penggunaan isolat bakteri selulolitik asal rayap disinyalir mampu meningkatkan degradasi senyawa selulosa sehingga biosuplemen yang dihasilkan mempunyai kualitas yang lebih baik. Penelitian Dewi et al., (2014) telah berhasil mengisolasi 10 isolat bakteri selulolitik asal rayap dan didapatkan dua terbaik dengan kode 3.3 dan 3.5 dengan tingkat degradasi substrat yang tinggi, masing-masing dengan diameter zone bening 0,412 cm; 0,730 cm dan 0,404 cm; 0,744 $\mathrm{cm}$ terhadap substrat Carboxymethylcellulose/CMC (sumber selulosa amorphorus) dan Avicel (sumber selulosa juga kristalin). Hasil penelitian Prabowo et al. (2007) menunjukkanbahwa isolat bakteri ekstrak rayap mempunyai aktivitas enzim $C M C$-ase yang sangat tinggi sebesar 0,6961-0,7638 U/mg dan kombinasinya dengan isolat bakteri lain yaitu isolat bakteri cairan rumen sapi atau kerbau menghasilkan aktivitas $C M C$ ase yang lebih besar daripada isolat tunggal.

Pemanfaatan isolat bakteri probiotik selulolitik asal rayap berbasis limbah isi rumen sapi bali berpotensi meningkatkan kualitas dan efektivitas biosuplemen yang dihasilkan. Namun informasi mengenai tingkat pemanfaatan inokulan isolat probiotik bakteri unggul asal rayap BR 3.5 dan BR 3.3 yang nantinya menjadi unggul 1 dan 2secara tunggal maupun kombinasinya dalam produksi biosuplemen berbasis limbah isi rumen serta bagi ternak masih belum banyak diperoleh, sehingga dilaksanakan penelitian pengaruh ransum tanpa danmenggunakan biosuplemen inokulan bakteri probiotik selulolitik cairan termites (Termites sp.)unggul 1 atau $2\left(\mathrm{RBCT}_{\mathrm{o}}, \mathrm{RBCT}_{1}, \mathrm{RBCT}_{2}\right.$, dan $\left.\mathrm{RBCT}_{1-2}\right)$ terhadap produktivitas itik bali jantan umur 2-10 minggu.

\section{MATERI DAN METODE}

\section{Itik Bali}

Itik yang digunakan dalam penelitian ini adalah itik bali jantan yang berumur dua (2) minggu sebanyak 75 ekor dengan rata-rata bobot awal yaitu 223,8 $\pm 16,18 \mathrm{~g}$.

\section{Kandang dan Perlengkapannya}

Kandang yang digunakan dalam penelitian ini adalah sistem kandang "battery colony" sebanyak 15 unit kandang dengan setiap unit kandang masing-masing diisi 5 ekor itik bali jantan. Pada setiap unit kandang sudah dilengkapi dengan nampan sebagai tempat pakan dan tempat air minum yang terbuat dari plastik.

\section{Kultur Isolat Bakteri Selulolitik}

Isolat bakteri rayap yang dipergunakan pada penelitian ini adalah isolat bakteri probiotik selulolitik unggul rayap 1 dan 2 (isolat bakteri dengan kode BR3.5 dan BR3.3) hasil penelitian Dewi et al. (2013). Sebelum isolat unggul dipakai dalam produksi biosuplemen, stock isolat terlebih dahulu dibiakkan dalam medium pertumbuhan cair selulolitik menggunakan medium Thioglicolate dengan $C M C$ sebagai substratnya.

\section{Medium Inokulan}

Medium inokulan yang digunakan dalam produksi bioinokulan penelitian ini yaitu, kombinasi sumber nutrien sintetis (proanalisis) dan alami dengan komposisi pada Tabel 1. 
Tabel 1. Komposisi bahan penyusun medium inokulan dalam 1 liter

\begin{tabular}{lc}
\hline \multicolumn{1}{c}{ Bahan Penyusun } & Komposisi \\
\hline Thioglycollate Fluid Medium/TFM (g) & 1 \\
Supernatan Cairan rumen (ml) & 10 \\
Molases (g) & 50 \\
Urea (g) & 1 \\
Asam tanat & 0,25 \\
CMC & 0,25 \\
Xylanosa & 0,25 \\
Jerami Padi (g) & 0,25 \\
Tepung Ketela Pohon (g) & 0,25 \\
Dedak Padi (g) & 0,25 \\
Garam Dapur (g) & 0,25 \\
Multi Vitamin-Mineral “Pignox" (g) & 0,15 \\
\hline
\end{tabular}

Sumber: Dewi et al.,(2014)

\section{Inokulan Isolat Bakteri Selulolitik Unggul Asal} Rayap dan Biosuplemen

Inokulan yang diproduksi dalam penelitian ini terdiri dari tiga jenis yaitu $\mathrm{CT}_{1}$ (inokulan bakteri probiotik selulolitikcairan termites unggul 1), $\mathrm{CT}_{2}$ (inokulan bakteri probiotik selulolitikcairan termites unggul 2) dan $\mathrm{CT}_{1-2}$ (inokulan bakteri probiotik selulolitik cairan termites unggul 1 dan 2 ). Produksi inokulan dilakukan dengan cara menginokulasikan $1 \%$ kultur isolat bakteri ke dalam medium inokulan.

Media biosuplemen berbasis limbah isi rumen akan diproduksi dengan memanfaatkan limbah dan gulma tanaman pangan dengan komposisi pada Tabel 2. Produksi biosuplemen dengan mencampur homogen seluruh bahan penyusun berbasis limbah isi rumen, dengan ditambahkan $0,5 \%$ kultur isolat probiotik terpilih sesuai perlakuan (0,5\% inokulan bakteri termites unggul terbaik 1 untuk $\mathrm{BCT}_{1 ;} \mathrm{O}, 5 \%$ inokulan bakteri termites unggul terbaik2 untuk $\mathrm{BCT}_{2} ; 0,25 \%$ $+0,25 \%$ inokulan bakteri termites unggul terbaik1 dan 2 untuk $\mathrm{BCT}_{1-2}$ ), kemudian dimasukan kedalam wadah plastik yang tertutup rapat dengan terisi penuh, selanjutnya diinkubasi dalam inkubator secara anaerob pada suhu $39^{\circ} \mathrm{C}$ selama 1 minggu. Setelah 1 minggu biosuplemen selanjutnya dikeringkan pada oven dengan suhu $39-42^{\circ} \mathrm{C}$ sampai kadar air produk $25-20 \%$. Produk biosuplemen digiling dan dimanfaatkan sebagai biosuplemen dalam ransum dengan tingkat pemberian $5 \%$.

\section{Ransum dan Air Minum}

Ransum basal yang digunakan dalam penelitian ini adalah ransum berbasis limbah dan gulma tanaman pangan, bahan penyusun disajikan pada Tabel 3 . Produksi ransum dilakukan dengan cara terlebih dahulu beberapa bahan penyusun ransum dikeringkan (baik menggunakan matahari, disangrai maupun oven)
Tabel 2. Komposisi bahan penyusun bahan medium biosuplemen ternak itik bali

\begin{tabular}{lc}
\hline \multicolumn{1}{c}{ Bahan Penyusun } & Komposisi (\% DM) \\
\hline Isi rumen & 20 \\
Dedak jagung & 8 \\
Dedak padi & 12 \\
Jagung kuning & 28 \\
Tepung kedele & 20 \\
Tepung tapioka & 5,2 \\
Molases & 4 \\
Tepung daun gamal & 0,8 \\
Eceng gondok & 0,8 \\
Daun apu & 0,8 \\
Garam dapur & 0,32 \\
Mineral-vitamin “Pignox” & 0,08 \\
\hline Total & 100
\end{tabular}

Keterangan: Komposisi bahan berdasarkan Hartadi (1990)

dan selanjutnya digiling halus. Produksi ransum basal dilakukan dengan cara mencampur homogen semua bahan penyusun ransum. Setelah itu ransum basal siap dimanfaatkan atau disuplementasi biosuplemen unggul sesuai perlakuan.

Ransum tersuplementasi biosuplemen $\left(\mathrm{R}_{0}, \mathrm{RBCT}_{0}\right.$, $\mathrm{RBCT}_{1}, \mathrm{RBCT}_{2}$ dan $\mathrm{RBCT}_{1-2}$ ) disusun dengan cara mencampur homogen $100 \%$ ransum basal dengan menambahkan $5 \%$ biosuplemen unggul (sesuai perlakuan).

Tabel 3. Komposisi bahan penyusun ransum basal ternak itik

\begin{tabular}{lrc}
\hline \multicolumn{1}{c}{ Bahan Penyusun } & $\begin{array}{c}\text { Komposisi } \\
\text { \% DM }\end{array}$ & $\begin{array}{c}\text { Komposisi As Fed } \\
\text { (g/kg Ransum) }\end{array}$ \\
\hline Jagung kuning & 35 & 406,97 \\
Dedak jagung & 10 & 120,36 \\
Dedak padi & 15 & 235,12 \\
Tepung kedele & 25 & 254,06 \\
Tepung tapioka & 6,5 & 72,83 \\
Tepung gamal & 1 & 10,51 \\
Molases & 5 & 58,81 \\
Garam Dapur & 0,4 & 4,34 \\
Mineral "pignox" & 0,1 & 1,09 \\
Eceng gondok & 1 & 137,30 \\
Daun apu & 1 & 136,40 \\
\hline Jumlah & 100 & 1191,48 \\
\hline
\end{tabular}

Keterangan: NRC (1984)

\section{Rancangan Penelitian}

Rancangan penelitian yang digunakan adalah rancangan acak lengkap (RAL) dengan 5 (lima) perlakuan dan di setiap perlakuan diulang tiga kali, sehingga terdapat 15 unit percobaan. Perlakuan yang diberikan yaitu: $\mathrm{RB}_{\mathrm{o}}=$ ransum basal tanpa menggunakan biosuplemen, $\mathrm{RBCT}_{\mathrm{o}}=$ ransum basal menggunakan biosuplemen tanpa penambahan isolat bakteri probiotik selulolitik cairan termites, $\mathrm{RBCT}_{1}=$ ransum basal menggunakan biosuplemen inokulan bakteri probiotik selulolitik cairan termites unggul 1, 
Tabel 4. Kandungan nutrisi ransum perlakuan dengan biosuplemen probiotik bakteri selulolitik unggul asal rayap

\begin{tabular}{|c|c|c|c|c|c|}
\hline \multirow{2}{*}{ Nutrien Ransum } & \multicolumn{5}{|c|}{ Perlakuan } \\
\hline & $\mathrm{R}_{0}$ & $\mathrm{RBCT}_{0}$ & $\mathrm{RBCT}_{1}$ & $\mathrm{RBBCT}_{2}$ & $\mathrm{RBCT}_{1-2}$ \\
\hline Bahan kering (\% DW basis) & 95,54 & 95,70 & 95,60 & 95,52 & 95,35 \\
\hline Bahan kering (\% as fed basis) & 72,77 & 74,23 & 71,14 & 70,10 & 69,34 \\
\hline Bahan organik (\% DM basis) & 76,17 & 74,17 & 72,66 & 72,83 & 73,10 \\
\hline Serat kasar (\% DM basis) & 5,68 & 5,70 & 5,60 & 5,56 & 5,65 \\
\hline Protein kasar (\% DM basis) & 17,48 & 17,48 & 17,60 & 17,75 & 17,50 \\
\hline Energy bruto (Kkal/kg) & 3,533 & 3,528 & 3,562 & 3,569 & 3,624 \\
\hline
\end{tabular}

Sumber : Hasil Analisis Laboratorium Nutrisi dan Makanan Ternak Fakultas Peternakan Universitas Udayana (2015).

$\mathrm{RBCT}_{2}=$ ransum basal menggunakan biosuplemen inokulan bakteri probiotik selulolitik cairan termites unggul 2 dan $\mathrm{RBCT}_{1_{2}}=$ ransum basal menggunakan biosuplemen inokulan bakteri probiotik selulolitik cairan termites unggul 1 dan 2.

\section{Variabel Penelitian}

Variabel yang diamati dalam penelitian ini adalah sebagai berikut:Bobot badan awal, bobot badan akhir, pertambahan bobot badan, konsumsi ransum, konversi ransum(FCR), bobot potong, persentase karkas dan pengukuran total kolesterol daging.

\section{Analisis statistika}

Data yang diperoleh dianalisis dengan sidik ragam dan bila terdapat perbedaan yang nyata $(\mathrm{P}<0,05)$ akan dilanjutkan dengan Uji Jarak Berganda Duncan (Steel and Torrie, 1993). Pengolahan data dianlisis menggunakan program aplikasi statistik SPSS 22 (Santoso, 2014).

\section{HASIL DAN PEMBAHASAN}

\section{Pengaruh Perlakuan terhadap Produktivitas Itik Bali Jantan Umur 10 Minggu}

Hasil penelitian penggunaan biosuplemen asal rayap (Termites sp.) terhadap bobot badan awal itik bali jantan umur 10 minggu menunjukan hasil yang tidak berbeda nyata $(\mathrm{P}>0,05)$ antar perlakuan $\mathrm{R}_{\mathrm{o}}, \mathrm{RBCT}_{\mathrm{o}}, \mathrm{RBCT}_{1}$, $\mathrm{RBCT}_{2}$ dan $\mathrm{RBCT}_{1-2}$ secara berturutan adalah $223,58 \mathrm{~g}$, 222,45 g, 223,01 g, 223,00 g dan 224,38 g. Sedangkan terhadap bobot badan akhir itik bali jantan yang diberi ransum dengan menggunakan biosuplemen asal rayap (Termites sp.) pada perlakuan $\mathrm{R}_{\mathrm{o}}$ adalah $988,39 \mathrm{~g} / \mathrm{ekor}$ (Tabel 5). Itik yang mendapatkan perlakuan $\mathrm{RBCT}_{0}$ menghasilkan bobot badan akhir 1,01\% tidak berbeda nyata lebih rendah $(\mathrm{P}>0,05)$ dibandingkan kontrol. Itik yang mendapat perlakuan $\mathrm{RBCT}_{2}$ menghasilkan bobot badan akhir 9,08\% nyata lebih tinggi $(\mathrm{P}<0,05)$ dengan kontrol, sedangkan terhadap perlakuan dan $\mathrm{RBCT}_{1-}$ ${ }_{2}$ menghasilkan bobot badan akhir berturut-turut yaitu 1011,17 g dan 1046,17 g lebih rendah dari perlakuan $\mathrm{RBCT}_{2}$ namun secara statistik berbeda tidak nyata
$(\mathrm{P}>0,05)$. Perbedaan bobot badan akhir yang nyata dalam penelitian ini erat kaitannya dengan ransum yang diberikan kepada ternak tersebut, selain itu juga disebabkan olehbiosuplemen yang diberikan, dimana biosuplemen yang diproduksi mengandung berbagai mikroba pendegradasi serat dan mikroba probiotik sehingga akan mampu meningkatkan metabolisme ransum serta dapat menutupi berbagai kekurangan/ kelemahan yang ada pada ransum berbasis limbah dan gulma tanaman pangan, sehingga pasokan nutrisi bagi ternak itik lebih baik dan produktivitas ternak yang dihasilkan akan meningkat (Dewi et al., 2014).

Terhadap konsumsi ransum itik bali jantan menunjukan bahwa pada perlakuan $\mathrm{RBCT}_{1}$ mempunyai rataan tertinggi sebesar $3849,33 \mathrm{~g}$ /ekor yaitu $1,78 \%$ dan $1,64 \%$ nyata lebih tinggi $(\mathrm{P}<0,05)$ dibandingkan dengan perlakuan $\mathrm{RBCT}_{2}$ dan $\mathrm{RBCT}_{0}$, sedangkan pada perlakuan $\mathrm{R}_{0}$ dan $\mathrm{RBCT}_{1-2}$ masing-masing lebih rendah $0,19 \%$ dan $1,32 \%$ dibandingkan $\mathrm{RBCT}_{1}$, namun secara statistik menunjukkan berbeda tidak nyata $(\mathrm{P}>0,05)$ (Tabel 5). Rendahnya konsumsi ransum tidak serta merta menurnkan bobot badan, yang dicerminkan oleh kebutuhan nutrisi ternak yang terpenuhi dengan baik dan metabolisme nutrien yang berlangsung dengan baik dan seimbang (Dewi et al., 2015).

Hasil yang sama didapat pada perlakuan $\mathrm{RBCT}_{2}$ yang memberikan hasil nyata $1,55 \%(\mathrm{P}<0,05)$ terendah bila dibandingkan dengan kontrol $\mathrm{R}_{0}$. Rendahnya konsumsi ransum yang dihasilkan pada penelitian ini dapat dikarenakan penggunaan inokulan probiotik selulolitik unggul cairan termites asal rayap pada biosuplemen sangat menguntungkan saluran pencernaan dan dapat mengoptimalkan konsumsi ransum, sehingga penyerapan zat-zat nutrisi berlangsung sempurna (Scott et al., 1982). Probiotik dapat memperbaiki saluran pencernaan dan meningkatkan kecernaan ransum, yaitu dengan cara menekan bakteri patogen dalam saluran pencernaan sehingga mendukung perkembangan bakteri yang menguntungkan yang membantu penyerapan zat zat makanan (Kompiang, 2009).

Rataan pertambahan bobot badan (PBB) itik bali jantan pada umur 10 minggu terhadap penggunaan biosuplemen probiotik selulolitik asal rayap (Termites 
Tabel 5. Pengaruh perlakuan terhadapproduktivitas itik bali jantan umur 2- 10 minggu

\begin{tabular}{|c|c|c|c|c|c|c|}
\hline \multirow{2}{*}{ Variabel } & \multicolumn{6}{|c|}{ Perlakuan ${ }^{1)}$} \\
\hline & $\mathrm{R}_{0}$ & $\mathrm{RBCT}_{0}$ & $\mathrm{RBCT}_{1}$ & $\mathrm{RBCT}_{2}$ & $\mathrm{RBCT}_{1-2}$ & $\mathrm{SEM}^{3)}$ \\
\hline Bobot badan awal (g) & $223,58^{a}$ & $222,45^{a}$ & $223,01^{a}$ & $223,00^{\mathrm{a}}$ & $224,38^{\mathrm{a} 2)}$ & 0,39 \\
\hline Bobot badan akhir (g) & $988,39^{a}$ & $978,42^{a}$ & $1011,17^{\mathrm{ab}}$ & $1078,17^{b}$ & $1046,17^{a b}$ & 21,15 \\
\hline onsumsi ransum (g) & $3841,67^{b}$ & $3787,33^{a}$ & $3849,33^{b}$ & $3782^{a}$ & $3798,67^{a b}$ & 16,40 \\
\hline Pertambahan bobot badan (g) & $764,81^{\mathrm{a}}$ & $755,97^{a}$ & $788,15^{\mathrm{ab}}$ & $855,17^{b}$ & $821,78^{\mathrm{ab}}$ & 20,86 \\
\hline Konversi ransum $(F C R)$ & $5,03^{b}$ & $5,01^{b}$ & $4,89^{b}$ & $4,42^{\mathrm{a}}$ & $4,63^{a b}$ & 0,14 \\
\hline Bobot potong (g) & $903,97^{\mathrm{a}}$ & $922,20^{\mathrm{a}}$ & $881,70^{\mathrm{a}}$ & $977,33^{\mathrm{a}}$ & $935,33^{\mathrm{a}}$ & 40,53 \\
\hline Persentase Karkas (\%) & $55,54^{\mathrm{a}}$ & $57,11^{\mathrm{a}}$ & $56,69^{a}$ & $57,67^{\mathrm{a}}$ & $55,14^{\mathrm{a}}$ & 0,78 \\
\hline Kolesterol daging (mg/dl) & $81,78^{e}$ & $71,64^{\mathrm{c}}$ & $73,09^{d}$ & $66,99^{a}$ & $68,17^{b}$ & 0,32 \\
\hline
\end{tabular}

Keterangan :

1) $\mathrm{RB}_{0}=$ Ransum basal tanpa menggunakan biosuplemen, $\mathrm{RBCT}=$ Ransum basal menggunakan biosuplemen tanpa penambahan isolat bakteri probiotik selulolitik cairan termites,

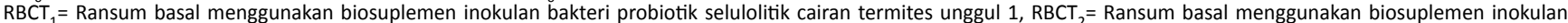
bakteri probiotik selulolitik cairan termites unggul 2 dan $\mathrm{RBCT}_{1}{ }^{-}{ }_{2}=$ Ransum basal menggunakan biosuplemen inokulan bakteri probiotik selulolitik cairan termites unggul 1 dan 2 . 2) Nilai dengan superskrip berbeda pada baris yang sama menunjukan perbadaan nyata $(P<0,05)$.

3) SEM : Standard Error of Treatment Means

sp.) dalam ransum dicantumkan pada Gambar 1. Hasil tertinggi ada pada perlakuan $\mathrm{RBCT}_{2}$ yaitu $15,74 \%$ nyata lebih tinggi $(\mathrm{P}<0,05)$ dibandingkan dengan $\mathrm{R}_{0}$, namun tidak berbeda nyata $8,5 \%$ dan $4,1 \%$ terhadap perlakuan $\mathrm{RBCT}_{1}$ dan $\mathrm{RBCT}_{1-2}$. Peningkatan bobot badan itik pada penelitian dapat dikarenakan dengan pemberian energi dan protein yang cukup dalam ransum (Tabel 4). Sedangkan pertambahan bobot badan pada itik dengan perlakuan $\mathrm{RBCT}_{1}$ dan $\mathrm{RBCT}_{1-2}$ masing-masing 3,05\% dan $7,45 \%$ lebih tinggi dibandingkan kontrol $\mathrm{R}_{\mathrm{o}}$, namun secara statistik berbeda tidak nyata $(\mathrm{P}>0,05)$. Hal ini disebabkan karena biosuplemen yang diproduksi pada ketiga perlakuan tersebut ditambahkan isolat probiotik selulolitik unggul cairan termites asal rayap. Biosuplemen tersebut mengandung berbagai mikroba pendegradasi serat dan mikroba probiotik sehingga dengan adanya sumber isolat probiotik selulolitik dalam ransum dapat membantu metobolisme ransum, meningkatkan aktivitas enzim-enzim pencernaan sehingga penyerapan zat zat makanan menjadi lebih sempurna (Kompiang, 2009, dan Dewi et al., 2013).

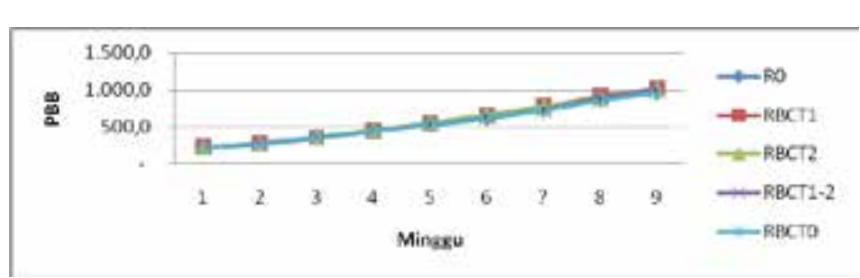

Gambar 1. Grafik pertambahan bobot badan itik bali jantan 2-10 minggu

Nilai Feed Convertion Ratio (FCR) pada penelitian ini menunjukkan hasil yang berbeda nyata $(\mathrm{P}<0,05)$ ratarata nilai FCR itik pada perlakuan $\mathrm{RBCT}_{2}$ nyata $(\mathrm{P}<0,05)$ lebih rendah 12,1\%, 9,6\% dan 11,78\% dibandingkan dengan perlakuan $\mathrm{R}_{0}, \mathrm{RBCT}_{1}$ dan $\mathrm{RBCT}_{0}$, sedangkan itik yang mendapatkan perlakuan $\mathrm{RBCT}_{1-2}$ yaitu $4,53 \%$ lebih tinggi, namun secara statistik menunjukan berbeda tidak nyata $(\mathrm{P}>0,05)$ terhadap perlakuan $\mathrm{RBCT}_{2}$ (Tabel
5). Feed Convertion Ratio (FCR) merupakan salah satu indikator yang dapat memberikan gambaran tentang tingkat efisiensi penggunaan ransum. Semakin rendah nilai FCR, maka semakin tinggi tingkat efisiensi penggunaan ransum (Anggorodi, 1995). Dari hasil penelitian didapatkan bahwa penggunaan biosuplemen probiotik selulolitik asal rayap (Termites $s p$.) nyata dapat meningkatkan efisiensi penggunaan ransum. Penurunan nilai FCR dipengaruhi oleh kecernaan nutrien ransum yang meningkat hal ini disebabkan karena adanya peningkatan populasi mikroba yang berasal dari biosuplemen yang diproduksi dari inokulan rayap yang mampu meningkatkan nutrien ransum, sehingga metabolisme nutrien ikut meningkat.

Bobot potong dan persentase karkas hasil penelitian mennunjukkan bahwa penggunaan biosuplemen probiotik selulolitik asal rayap (Termites $s p$.) $\mathrm{RBCT}_{\mathrm{o}}$ $\mathrm{RBCT}_{1}, \mathrm{RBCT}_{2}$ dan $\mathrm{RBCT}_{1-2}$ dalam ransum tidak berpengaruh nyata $(\mathrm{P}>\mathrm{O}, 05)$ terhadap bobot potong dan persentase karkas. Terhadap bobot potong itik umur 10 minggu yang mendapatkan perlakuan $\mathrm{RBCT}_{2}$ memberikan hasil yaitu 8,12\%, 5,98\%, 10,85\%, 4,49\% tidak berbeda nyata $(\mathrm{P}>0,05)$ lebih tinggi dibandingkan dengan perlakuan $\mathrm{R}_{0}, \mathrm{RBCT}_{0}, \mathrm{RBCT}_{1}$ dan $\mathrm{RBCT}_{1-2}$. sedangkan pada perlakuan $\mathrm{RBCT}_{1}$ memberikan hasil lebih rendah 2,46\% dibandingkan dengan kontrol $\left(R_{0}\right)$ secara statistik tidak berbeda nyata (Tabel 5). Persentase karkas merupakan perbandingan antara bobot karkas dan bobot potong dikalikan 100\%. Persentase karkas itik bali jantan pada perlakuan $\mathrm{RBCT}_{0}, \mathrm{RBCT}_{1}$ dan $\mathrm{RBCT}_{2}$ masing-masing yaitu $2,83 \%, 2,07 \%$ dan $3,84 \%$ lebih tinggi dibandingkan dengan $\mathrm{R}_{\mathrm{O}}$, namun secara statistik tidak berbeda nyata $(\mathrm{P}>0,05)$ sedangkan pada perlakuan $\mathrm{RBCT}_{1-2}$ memberikan hasil o,72\% lebih rendah $(\mathrm{P}>0,05)$ secara statistik tidak berbeda nyata.

Terhadapkandungan kolesterol daging itikbalijantan tanpa/dengan biosuplemen unggul asal rayap pada perlakuan $\mathrm{R}_{\mathrm{o}}$ adalah $81,78 \mathrm{mg} / \mathrm{dl}$ (Tabel 5). Persentase kolesterol daging pada perlakuan $\mathrm{R}_{\mathrm{o}}$ masing-masing 
$14,15 \%, 11,89 \%, 22,07 \%$ dan $19,96 \%$ nyata $(\mathrm{P}<0,05)$ tertinggi dibandingkan dengan perlakuan $\mathrm{RBCT}_{\mathrm{o}}$ $\mathrm{RBCT}_{1}, \mathrm{RBCT}_{2}$ dan $\mathrm{RBCT}_{1-2}$, Rataan kolesterol daging pada penelitian dapat dikatakan dibawah rata-rata kolesterol normal yaitu $130 \mathrm{mg} / \mathrm{dl}$. Hal ini disebabkan oleh karena biosuplemen probiotik selulolitik asal rayap (Termites sp.) mengandung mikroba (bakteri, kapang/fungi, dan protozoa), yang menghasilkan enzim pencerna serat kasar, sehingga dapat menghambat pembentukan kolesterol oleh enzim HMG-KoA reduktase (Hydroksimetyl glutaryl-KoA). Tingginya aktivitas enzim yang dihasilkan oleh inokulan probiotik selulolitik unggul 1 dan 2 mengakibatkan kandungan kolesterol karkas menjadi rendah. Hal ini dikarenakan enzim yang dihasilkan mensitesis kolesterol yang dimulai dari konversi asetil-KoA menjadi $H M G K o A$ reduktase (3-hidroksi-3-metilglutaril-KoA) menurun. Selanjutnya dilanjutkan oleh konversi $H M G$ KoA menjadi mevalonat, kemudian mevalonat dikonversi menjadi isopentil pirofosfat (IPP) bersama dengan hilangnya $\mathrm{CO}_{2}$, konversi isopentil pirofosfat (IPP) menjadi squalen menyebabkan squalen menurun, sehingga hasil dari konversi squalen mengakibatkan tidak terjadinya pembentukan kolesterol yang berasal dari asam lemak jenuh (Guyton dan Hall, 2007).

\section{SIMPULAN}

Berdasarkan hasil penelitian dapat disimpulkan bahwa penggunaan biosuplemen berprobiotik bakteri selulolitik asal rayap (Termites sp.) $\mathrm{RBCT}_{0}, \mathrm{RBCT}_{1}$, $\mathrm{RBCT}_{2}, \mathrm{RBCT}_{1-2}$ memberikan pengaruh yang lebih baik dibandingkan dengan kontrol $\mathrm{R}_{\mathrm{O}}$. Penggunaan ransum basal menggunakan biosuplemen inokulan bakteri probiotik selulolitik cairan termites unggul $2\left(\mathrm{RBCT}_{2}\right)$ mampu meningkatkan produktivitas itik bali jantan umur 2-10 minggu.

\section{UCAPAN TERIMAKASIH}

Penulis mengucapkan terimakasih kepada Ibu Prof. Dr. Ir. Gst. Ayu Mayani Kristina Dewi, MS, Bapak Prof. Dr. Ir. Nyoman Sutarpa Sutama, MS, yang telah memberikan masukan dalam perbaikan penulisan artikel ini.

\section{DAFTAR PUSTAKA}

Anggorodi. 1995. Nutrisi Aneka Ternak Unggas. Jakarta (Indones): PT. Gramedia Pustaka Utama.

Dewi, G.A.M. K, I.W Wijana, N W. Siti dan I.M. Mudita. 2013. Optimalisasi Pemanfaatan Limbah Dan Gulma Tanaman Pangan Dalam Usaha Peternakan Itik Bali Melalui Produksi Biosuplemen Berprobiotik Berbasis
Limbah Isi Rumen.Laporan Penelitian Hibah Penelitian Unggulan Udayana.

Dewi, G. A. M. K., I N. S. Sutama, dan I W. Wijana. 2014. Isolasi dan Pemanfaatan Probiotik Bakteri Selulolitik Asal Rayap Untuk Produksi Biosuplemen Berbasis Limbah Rumen dalam Optimalisasi Peternakan Itik Bali Rakyat. Laporan Penelitian Tahap 1. Fakultas Peternakan. Universitas Udayana, Denpasar.

Dewi, G.A.M.K., I N. S. Sutama, I W. Wijana, dan I M. Mudita. 2015. Performans dan Produksi Karkas Itik Bali yang Mendapat Ransum Biosuplemen Berbasis Limbah Isi Rumen. Proseding Seminar Nasional Tentang Unggas Lokal Ke-V dan Kongres Masyarakat Perunggasan Indonesia. Semarang 18-19 November 2015. Fakultas Peternakan dan Pertanian Universitas Diponegoro Semarang: 355-365.

Dijaya, A.S. 2003. Penggemukan Itik Jantan Potong. Penebar Swadaya, Jakarta.

Guyton, A.C., dan Hall, J.E. 2007.Buku Ajar Fisiologi Kedokteran.Jakarta: Penerbit Buku Kedokteran (EGC).

Hartadi, H. S. 1990. Komposisi Bahan Pakan Untuk Indonesia.Gadja Mada University Press, Yogyakarta.

Kompiang, I.P. 2009.Pemanfaatan mikroorganisme sebagai probiotik untuk meningkatkan produksi ternak unggas di Indonesia. Jurnal Pengembangan Inovasi Pertanian2 (3): 177-191.

Mudita, I M., A. A. P. P. Wibawa, dan I W. Wirawan. 2014. Isolasi dan Pemanfaatan Konsorsium Bakteri Lignoselulolitik Kolon Sapi Bali dan Sampah TPA Sebagai Inokulan Biosuplemen Berprobiotik Peternakan Sapi Bali Berbasis Limbah Pertanian. Laporan Penelitian Hibah Bersaing Tahun I.

National Research Council (NRC). 1984. Nutrient Requirement of Poultry. 7th National Academy Sciences, Washington DC.

Partama, I. B. G., I M. Mudita, N. W. Siti, I W. Suberata, dan A. A. A. S. Trisnadewi. 2012. Isolasi, Identifikasi dan Uji Aktivitas bakteri serta Fungi Lignoselulolitik Limbah Isi Rumen dan Rayap Sebagai Sumber Inokulan dalam Pengembangan Peternakan Sapi Bali Berbasis Limbah. Laporan Penelitian Invensi. Universitas Udayana, Denpasar.

Prabowo, A., S. Padmowijoto, Z. Bachrudin, dan A. Syukur. 2007. Potensi Mikrobia Selulolitik Campuran dari Ekstrak Rayap, Larutan Feses Gajah dan Cairan Rumen Kerbau. Balai Pengkajian Teknologi, Palembang.

Santoso, Singgih. 2014. SPSS 22 from Essential to Expert Skills. Jakarta: PT Elex Media Komputindo.

Scott, M.L.,M.C.Neisheim and R.J.Young. 1982. Nutrition of The Chickens. 2nd Ed. Ithaca, New York: Publish by: M.L. Scott and Assoc.

Steel, R. G. D and J. H. Torrie. 1993. Principle and Procedures of Statistic, $2^{\text {nd }}$ Ed. McGraw Hill Internasional Book Co. London. 